\title{
Roztańczone słowa. Potencjał teatralny sceny balu w Romeo i Julii Williama Szekspira. Część 2
}

\author{
Dancing Words. Theatrical Potential of the Ball Scene in Shakespeare's Romeo and Juliet. \\ Part II
}

\begin{abstract}
The function of dance in Shakespeare's plays, as in all Renaissance culture, has its roots in the antiquity in which dance symbolized concord and harmony that reflected the cosmic movements of celestial bodies. In this context the significance of dance in the ball scene at the beginning of Romeo and Juliet presents itself as a fascinating material to be studied from the perspective of the theatrical potential of the dramatic text. In this scene, music and dance play a symbolical role the aim of which is to highlight the dramatic irony realized by the fusion of rhetorical language and choreography, with the rich formalized poetic language and the ball situation as the key elements of the plot. This fusion opens a range of possible theatrical interpretations, each decision having a major influence on the meaning of this episode. In the article the ball scene is analyzed from the literary, dramatic and historical perspective. The realization of its theatrical potential is illustrated with chosen stage productions which prove this scene's crucial role in suggesting possible interpretations of the whole tragedy.
\end{abstract}

Keywords: Romeo and Juliet, dance, theatrical potential, ball scene

\begin{abstract}
Abstrakt: Funkcja tańca w sztukach Szekspira, podobnie jak w całej kulturze renesansu, ma swoje korzenie w starożytności, w której taniec symbolizował zgodę i harmonię odzwierciedlającą kosmiczne ruchy ciał niebieskich. W tym kontekście znaczenie tańca w scenie balowej na początku Romea i Julii jawi się jako fascynujący materiał do przestudiowania pod kątem teatralnego potencjału tekstu tego dramatu. W analizowanej scenie muzyka i taniec pełnią funkcję symboliczną, której celem jest podkreślenie dramatycznej ironii realizowanej przez połączenie języka retoryki i choreografii z bogatym, sformalizowanym językiem poetyckim i sytuacją balową jako kluczowymi elementami fabuły. Takie połączenie otwiera wiele możliwych interpretacji teatralnych, a każda decyzja ma duży wpływ na znaczenie tego epizodu dramatu. W artykule scena balu została przeanalizowana z perspektywy literackiej, dramatycznej i historycznej. Realizację jej teatralnego potencjału ilustrują wybrane interpretacje sceniczne, które świadczą o kluczowej roli tej sceny w proponowaniu możliwych interpretacji całej tragedii.
\end{abstract}

Słowa kluczowe: Romeo i Julia, taniec, potencjał teatralny, scena balowa 
Analiza odniesień do tańca w scenie balu u Kapuletów, przedstawiona w części 1 artykułu, unaoczniła, że jest on kluczowym elementem aktu otwierającego tragedię. Elementem, który generuje i współtworzy znaczenia istotne dla interpretacji nie tylko tego epizodu, ale także całej sztuki. Począwszy od opisania miejsca i roli tańca w kulturze renesansowej Anglii oraz jego funkcjonowania w sztukach Szekspira, skupiłam się następnie na przeanalizowaniu potencjału teatralnego sceny balowej w odniesieniu do jej poszczególnych aspektów. W skali makro, czyli na płaszczyźnie znaczeń istotnych dla interpretacji całości sztuki, bal w domu Julii jest momentem chwilowego zazębienia prywatnego świata miłości oraz publicznego świata waśni między rodzinami kochanków. W skali mikro, tworzącej znaczenia bezpośrednio dotyczące tej sceny, bal jest okazją do nakreślenia pozycji społecznej poszczególnych postaci oraz sieci zależności emocjonalnych między nimi, a sam taniec płaszczyzną epifanicznego odkrycia, a następnie spotkania głównych bohaterów, w którym główną rolę odgrywa współistnienie dialogu i ruchu scenicznego. Przedstawione poniżej historyczne studium na temat prawdopodobnego sposobu wystawienia sceny balu oraz współczesne rozwiązania sceniczne pozwalają uświadomić sobie bogactwo potencjału teatralnego tej sceny, które niewątpliwie przyczynia się do niesłabnącej popularności tragedii kochanków z Werony wśród twórców teatralnych i publiczności.

\section{Bal u Kapuletów na scenie za czasów Szekspira}

Jak mogła wyglądać scena balowa przedstawiana na deskach publicznego teatru za czasów Szekspira? Powołam się tutaj na opis Johna Styana z jego klasycznej książki Shakespeare’s Stagecraft. W rozdziale na temat ruchu scenicznego, zatytułowanym wymownie „Gest określony i gest implikowany”, badacz stwierdza, że Szekspir pisał ,poezję gestyczną” (gestic poetry). Dobra poezja dramatyczna bowiem, według Styana, implikuje gest i ruch, tak jak ludzka mowa służy, między innymi, odzwierciedleniu stanów fizycznych. Podając wiele przykładów na „związek między ruchem ciała a impulsami mowy", wymienia sonet w scenie balowej, który poprzez swoją formę i obrazowanie służy aktorom za materiał, za pomocą którego konstruują oni dialog Romea i Julii. Sonet ten nie tylko buduje tonację właściwą dla wyidealizowanej sytuacji miłosnej, ale także zawiera precyzyjne wskazówki w odniesieniu do gestów i postawy ciała. Zdaniem Styana Romeo w tym momencie nie tańczy z Julią, ale sugerowany przez czterowiersze rytm koresponduje z rytmem dworskiego tańca, którego figury zbliżania się i wycofywania symbolizują zaloty kawalera i nieskorość skromnej damy. Z kolei w rozdziale pod tytułem „Planowanie w trzech wymiarach” historyk szczegółowo uzasadnia swoje wyobrażenie sceny balu u Kapuletów technicznymi uwarunkowaniami sceny elżbietańskiej, zwłaszcza jej trójwymiarowością, twierdząc, że scena teatru publicznego pod gołym niebem stymulowała w dramaturgach poczucie relacji przestrzennych. Styan przedstawia Szekspira jako autora tekstów dających aktorom możliwość poruszania się w dużej przestrzeni i tworzącego

\footnotetext{
1 J.L. Styan, Shakespeare's Stagecraft, Cambridge 1967, s. 56.
} 
rodzaj renesansowego teatru tańca (Renaissance dance-drama) ${ }^{2}$. Przypomina, że wykorzystanie pierwszego i drugiego planu, czyli przodu i tyłu sceny, a także balkonu i dwojga drzwi służyło konwencjom, takim jak wypowiedzi „,na stronie”, podsłuchiwanie, podglądanie, a także tworzeniu dwóch lub więcej planów czy sygnalizowaniu konfliktu.

Tak więc Styan uważa, że do domu Kapuleta damy miały wchodzić jednymi drzwiami, kawalerowie zaś drugimi, aby zasygnalizować ich oddzielenie i stworzyć przestrzeń dla zabiegów retorycznych i gestów, za pomocą których gospodarz łączy ich w taneczne pary. Taniec rozgrywał się, zdaniem badacza, w głębi sceny w centrum, gospodarz natomiast i jego kuzyn wycofywali się ku jednemu z boków z tyłu sceny, tak aby przód sceny pozostawić dla antagonistów - Romea i Tybalta. Styan uważa, że monolog „O, she doth teach the torches to burn bright!” był wypowiadany bezpośrednio do widzów (czyli z zastosowaniem konwencji „na stronie”), przy równoczesnym spoglądaniu w głąb sceny na Julię. Oznacza to, że Romeo występował w podwójnej roli - postaci i chóru. Jako postać Romeo patrzy na Julię, jako chór - komunikuje widzom swój stan zakochania. Akcja rozgrywa się na dwóch planach: ruch w głębi sceny przyciąga oko, słowo wypowiadane na froncie - wpada w ucho (ustanawiając, jak widzieliśmy powyżej, kluczowe obrazowanie). Wkrótce nad sceną pierwszego zauroczenia zawisa chmura konfliktu, co zostaje zasygnalizowane symbolicznym wykorzystaniem przestrzeni, czyli rozmieszczeniem Romea i Tybalta po przeciwległych stronach. Styan widzi więc $\mathrm{w}$ tej scenie pięć centrów uwagi rozmieszczonych w trójwymiarowej przestrzeni, które chwilami oddziaływają na widzów wymiennie, chwilami się nakładają, chwilami konkurują o ich uwagę.

Oczywiście takie tradycyjne zagospodarowanie przestrzeni bardzo rzadko występuje w dzisiejszych inscenizacjach, ale i tak odnajdziemy w nich wiele z elementów, o których Styan mówił z perspektywy historyka teatru. Natomiast badaczy tekstu - zarówno dawniej, jak i dziś - nieodmiennie fascynuje ciężar znaczeniowy, jaki niesie zestawienie sytuacji tańca z sytuacją wrogości, kiedy uświadamiamy sobie, że „muzyka i taniec pełnią retoryczną i symboliczną funkcję mającą na celu wzmocnienie ironii dramatycznej" ${ }^{3}$. Zestawienie to częściowo znajduje wyjaśnienie w konwencji tragedii elżbietańskiej i jakobińskiej, zwłaszcza tragedii zemsty, w której taniec bywał przykrywką dla śmiercionośnego zła. U Johna Marstona czy Johna Forda odnajdujemy motywy, takie jak zamaskowani tancerze, którzy okazują się mordercami, czy zabójstwa dokonywane podczas tańca ${ }^{4}$. W Romeo i Julii zło nie ukrywa się bezpośrednio w tańcu, ale ze względu na jego okoliczności jest z nim subtelnie związane. Paradoksalnie, a przez to wyraziście, symbol zgody i harmonii jest zarazem złowrogą zapowiedzią śmierci. Dzięki połączeniu retoryki mowy z choreografią tańca dochodzi do znakomitego efektu: efemeryczna, będąca zaprzeczeniem wszelkiej przemocy, czynność tańca

\footnotetext{
2 Ibid., s. 81.

3 J.H. Long, Shakespeare's Use of Music. The Histories and Tragedies, Gainesville 1971, s. 70.

${ }^{4}$ A. Brissenden, Shakespeare and the Dance, New Jersey 1981, s. 63.
} 
staje się przeciwwagą dla wielokrotnych zabójstw, do których dochodzi w dalszej części sztuki ${ }^{5}$.

\section{Realizacja tańca w scenie balu - polemiki}

W tym miejscu wypada streścić argumenty badaczy, którzy w sporze o to, czy młodzi tuż przed swoją pierwszą rozmową lub w jej trakcie tańczą, czy też nie tańczą, wyraźnie dzielą się na dwie grupy. Wielu autorów powołuje się na tekst dialogu, który implikuje dystans Romea wobec tanecznej zabawy ${ }^{6}$. Jest kilka takich wskazówek. W poprzedniej scenie Romeo następująco wyraża wątpliwości co do planu wtargnięcia na bal u Kapuletów:

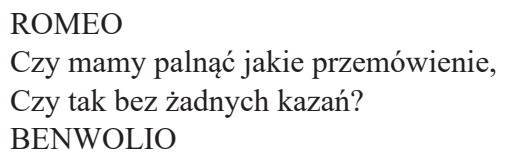

Według tradycyjnej organizacji dworskich zabaw tego typu, przejęcie pochodni oznaczało, że uczestnik nie będzie tańczył ${ }^{7}$. Poza tym Romeo uzasadnia swoją niezdolność do tańca przytłaczającą melancholią: obrazowanie wyraźnie zestawia lekkość tanecznego kroku z ciężarem smutku. To, że po wejściu do sali balowej Romeo rzeczywiście trzyma pochodnię, zdaje się potwierdzać pierwsza linijka monologu na widok Julii, pierwszy obraz poetycki - porównanie blasku dziewczyny z blaskiem pochodni: „Światłość jej rysów gasi w moim oku / Płomień pochodni!". W dodatku na końcu sceny Julia dopytuje się Piastunki o tożsamość Romea, wskazując wśród wychodzących tego, który „nie chciał tańczyć” (Bar) „What's he that follows here, that would not dance?”. I właśnie ta odmowa udziału w tańcu jest już na tym etapie sygnałem rodzącego się konfliktu. Przecież staremu Kapuletowi szczególnie zależy właśnie na tym, aby młodzi uczestnicy balu

${ }^{5}$ F. Hazrat, "The Wisdom of Your Feet". Dance and Rhetoric on the Shakespearean Stage [w:] The Oxford Handbook on Shakespeare and Dance, Oxford 2019, s. 231.

6 J.L. Styan, op. cit.; Ph. McGuire, On the Dancing in "Romeo and Juliet”, „Renaissance and Reformation” 1981, New Series 5, nr 2, s. 87-97; W. Sorell, Shakespeare and the Dance, „Shakespeare Quarterly" 1957, vol. 8, nr 3, s. 367-384.

${ }^{7}$ B. Gibbons, Introduction [w:] W. Shakespeare, Romeo and Juliet, London 1980, s. 106. 
oddali się tanecznym pląsom. Ojciec Julii zachęca, a wręcz zagania, gości do tańca właśnie dlatego, żeby pokazać, że u niego w domu dobrze się dzieje, że panuje porządek, pokój i bezpieczeństwo. Dla niego, jako przywódcy tej wspólnoty, taniec ma znaczenie polityczne i wymowę symboliczną, którą wprawnie się posługuje.

Ale jest też grupa badaczy powołujących się na otwartość sceniczną tekstu, na brak wyraźnych didaskaliów, które rozwiązywałyby tę kwestię, i twierdzących, że decydującą rolę w interpretacji powinna mieć sceniczna efektywność połączenia młodych w tańcu w którymś momencie tego epizodu ${ }^{8}$.

Romeo może przyłączyć się do tańczących po to, aby móc zwrócić się do Julii, manifestując w ten sposób opuszczenie kręgu obsesyjnego uczucia wobec Rozaliny i wejście w orbitę prawdziwej miłości, której doskonałość symbolizuje harmonia tańca. Chociaż z zapisu nie wynika, czy młodzi tańczą czy nie, ich udział w powolnej i uroczystej pawanie, w tradycji kulturowej kojarzonej z zalotami prawdziwie zakochanych, zdecydowanie ma sens?

Wspomniany wcześniej Hoskins podziela taką wizję i uzasadnia ją tym, że measure (pawana lub menuet, taniec mający swoje korzenie w ludowym chodzonym) był tańcem powolnym, pozostawiającym tancerzom dużo czasu i przestrzeni na rozmowę lub flirt ${ }^{10}$.

Ciekawe, że Brissenden, który także uważa, że Romeo i Julia nie łączą się w tańcu, również powołuje się na teatralną efektywność, tyle że, według niego, efekt zasadza się właśnie na wyjęciu młodych z roztańczonego tła. Opierając się na innym niż Hoskins rozumieniu słowa measure, badacz ten uważa, że Benwolio używa measure na określenia tańca w ogóle, Romeo natomiast mówiąc, „The measure done, I'll watch her place of stand” („Gdy przerwie taniec, przybliżę się do niej”), ma na myśli pewną część włoskiego tańca o wielu figurach tańczonych w różnym tempie, zwanym ballo. Brissenden widzi więc to tak: Romeo nie tańczy, lecz czeka, aż Julia skończy swoją figurę. Ona niejako wychodzi ku niemu z tego tańca, spotykają się, rozmawiają i całują na tle tańca i muzyki, których klimat podkreśla ten wyjątkowy moment, a także ustanawia silnie ironiczny kontrast wobec dysharmonii, która nastąpi. Tyle że to właśnie unieruchomienie zakochanych, fakt, że nie biorą oni udziału w tym regularnym harmonijnym ruchu, odizolowuje ich od schematycznego porządku, odcina ich od niego ${ }^{11}$. Czyli - wizualnie zostaje tu zasygnalizowana ich niezgoda na zasady, którymi kierują się mieszkańcy Werony. Brissenden ma także ciekawe uwagi na temat wspomnianej wyżej pochodni - rekwizytu, który współgra z centralnym obrazowaniem związanym z blaskiem, gwiazdami i światłością skontrastowaną z ciemnością nocy. Zauważa, że w jednej z wersji historii nieszczęśliwych kochanków (która była przecież niezwykle popularna w renesansowej Europie i na różne sposoby przepisywana i modyfikowana), we włoskiej noweli Luigiego da Porto Istoria novellamente ritrovata di due nobile amanti (1535), jest mowa o tańcu z pochodniami (il ballo de

\footnotetext{
8 J.H. Long, op. cit.; F. Hazrat, op. cit.; J. Hoskins, The Dances of Shakespeare, New York 2005.

9 F. Hazrat, op. cit., s. 231.

10 J. Hoskins, op. cit., s. 74.

11 A. Brissenden, op. cit., s. 64.
} 
torchio), tradycyjnie tańczonym na zakończenie dworskich bankietów. W wersji da Porto Julia tańczy z Romeem i Merkucjem jedną z figur tego tańca, w której brało udział troje tancerzy, kobieta w środku, po obu stronach trzymając za ręce swoich partnerów. Również w wierszu Brooke'a The Tragical History of Romeus and Juliet (1562) mowa jest o rycerzu, który, trzymając w ręku pochodnię, prowadzi Julię do tańca.

\section{Przykładowe rozwiazania sceniczne}

Przedstawione powyżej rozważania zilustruję omówieniem czterech współczesnych interpretacji sceny balowej. Będzie to teatr telewizji brytyjskiej Thames Television z roku 1976 w reżyserii Joan Kemp-Welch, inscenizacja londyńskiego teatru Shakespeare's Globe z roku 2009 w reżyserii Dominica Dromgoole'a, przedstawienie szkolnego teatru w australijskim Gungahlin College z roku 2013 oraz inscenizacja Royal Shakespeare Company z roku 2018 w reżyserii Eriki Whyman. Moje obserwacje opieram na nagraniach udostępnionych przez Shakespeare's Globe oraz Gungahlin College Theatre na kanale YouTube, na fragmentach przedstawienia RSC dostępnych online w ramach Shakespeare Learning Zone (linki podane w wykazie literatury) oraz na zapisie DVD w przypadku produkcji Thames Television. $Z$ wyjątkiem tego ostatniego materiału istnieje oczywista trudność metodologiczna w przypadku analiz opartych na nagraniach przedstawień teatralnych. W sytuacji nagranych przedstawień nie mamy dostępu do wszystkich aspektów interesujących nas scen, gdyż inscenizacja jest ograniczona „okiem kamery”, analiza może być więc obarczona pewnym marginesem błędu. Mimo to dostępny materiał oceniam jako wystarczający na potrzeby mojego omówienia. Wybór tych właśnie przedstawień jest podyktowany kilkoma względami. Po pierwsze, zależało mi na zestawieniu inscenizacji kostiumowych, a zarazem tych, które można określić mianem tradycyjnych i które wykorzystują taniec stylizowany na taniec $\mathrm{z}$ epoki, z interpretacjami uwspółcześniającymi. Po drugie, chodziło mi o subtelne zróżnicowanie dominującego nastroju, co w otwarciu sztuki ma istotne przełożenie na kształtowanie oczekiwań widza i możliwości manipulowania jego emocjami. Po trzecie, nie chciałam ograniczać pola obserwacji do instytucji teatralnych i reżyserów o ustalonej reputacji. Po latach analizowania tego utworu ze studentami zawsze ciekawi mnie, jak zagraliby go młodzi amatorzy.

Romeo i Julia w reżyserii Joan Kemp-Welch z Christopherem Neame i Ann Hasson w rolach głównych to inscenizacja kostiumowa i trzymająca się blisko tekstu. Wystrój sali balowej w domu Kapuleta utrzymany jest w ciepłych kolorach złota i ochry, światło jest przyćmione. Na tym tle rudobrązowy strój Romea zdaje się wspierać jego kamuflaż i zamiar nierzucania się zbytnio w oczy. Niewielka przestrzeń sali balowej, sprawiająca wrażenie wręcz ciasnej, jest ograniczona od strony wejścia kilkoma stopniami szerokich schodów, z pozostałych stron - filarami. Scena rozpoczyna się długą sekwencją spokojnego dworskiego tańca. W pierwszym układzie Julia tańczy pomiędzy dwoma tancerzami, następne figury i obroty rozdzielają i mieszają partnerów, ale dominującym elementem po- 
zostaje lekkie dotykanie się przez partnerów spodem dłoni raz prawej, raz lewej ręki. Taniec ten jest dostojny, przystojny i raczej pozbawiony większych emocji. Maski na twarzach mają jedynie mężczyźni i tylko ci, którzy uczestniczą w tańcu, z wyjątkiem Romea, którego oczy i połowa twarzy także są zasłonięte maską. Romeo obserwuje taniec, a kiedy zauważa Julię, zaczyna dyskretnie krążyć po sali i wokół tańczących. Julia obrzuca go krótkim spojrzeniem, ale potem nie zwraca na niego uwagi, zaangażowana $\mathrm{w}$ taniec $\mathrm{z}$ wyraźną przyjemnością i poruszając się z gracją. Romeo wygłasza swój monolog w sposób zdecydowanie statyczny - kamera unieruchamia jego postać, filmując ujęcie twarzy. Tańca więc nie widzimy, ale jesteśmy go świadomi dzięki muzyce i oczom Romea podążającym za Julią.

Ciekawie rozwiązano kłótnię Tybalta z wujem: wyraziste jest w tej scenie użycie tańca w funkcji symbolicznej. Ujęcie dzieli się na trzy plany. Gniewna dyskusja Kapuleta z siostrzeńcem rozgrywa się na pierwszym z nich, na tle tańczących gości, którzy w centralnym miejscu sali tworzą plan drugi. Istotne jest przy tym, że choreografia przewiduje na ten moment rozmaite układy tańca po kole, a więc symbol wspólnoty zostaje silnie skontrastowany z konfliktem w obrębie rodziny. $\mathrm{Na}$ trzecim planie, w głębi, na schodach, nieco ponad tańczącymi umieszczono obserwującego wszystko Romea. Taniec kończy się oklaskami, a zanim rozpocznie się kolejny, następuje chwilowe zamieszanie, które Romeo wykorzystuje na zmianę miejsca. Julia nie bierze udziału w tym drugim tańcu, stojąc opodal filara, co pozwala Romeowi podejść ukradkiem i od tyłu ująć ją za rękę. Ona jest bardzo zdziwiona, pozwala się jednak wyprowadzić pośpiesznie w kierunku korytarza. Młodzi zatapiają się w sonetowym flircie na tle tanecznej muzyki dochodzącej z sali balowej. Rozmawiając, dotykają się dłońmi, palm to palm, i jest to ten sam gest, który przed chwilą Julia wykonywała w tańcu. Nie tańczą dosłownie, ale ich ciała naśladują taneczne gesty. Dla Julii Romeo staje się niejako kolejnym partnerem, a on sam dopiero teraz, zdobywszy upatrzoną wcześniej partnerkę, angażuje się w taniec. Rozwiązanie takie przynosi dwojaki efekt. Z jednej strony, wydobywa młodych z tła, separuje ich od grupy, pozwala na intymną rozmowę w intymnej przestrzeni i do pewnego stopnia zapewnia im bezpieczeństwo, bo pozostali są zajęci tańcem. Z drugiej strony, subtelnie generuje suspens dzięki zestawieniu konwencjonalnych układów tanecznych odgrywanych przez tancerzy w sali z wykraczającym poza konwenans, chociaż pozornie go naśladującym, zachowaniem Romea i Julii. Kiedy przy okazji pocałunków ich dłonie splatają się w zdecydowanie bardziej erotyczny uścisk, niepokój widza staje się równy temu, który towarzyszył kłótni Tybalta ze starym Kapuletem. Coś musi się wydarzyć. Niebezpieczeństwo jest tuż-tuż. A jednak nie zagrozi jeszcze młodym tym razem. W interpretacji Kemp-Welch scena balu u Kapuletów kończy się zaskakująco pogodnie. Niby ktoś komuś szepce coś na ucho, spod ściany błyska wrogim okiem Tybalt, ale Romeo i Merkucjo wychodzą spokojnie, żegnani wylewnie przez gospodarza. Nie ma przeciągłych spojrzeń między zakochanymi, Julia robi tylko kilka kroków w kierunku drzwi, za którymi zniknął Romeo.

Inscenizację teatru Globe również można określić jako tradycyjną. Aktorzy ubrani są w stroje z epoki Szekspira, a na scenie rozbrzmiewają melodie renesansowych tańców. Główne role grają młodzi aktorzy, Ellie Kendrick i Adetomiwa 
Edun, pełni młodzieńczego entuzjazmu, przy czym Kendrick ma warunki i urodę bardzo młodej dziewczyny, więc jej Julia to faktycznie czternastolatka. Scena rozpoczyna się i kończy w tonacji bardzo pogodnej. Przestrzeń jest jasno oświetlona, a kolory kostiumów pastelowe i ciepłe.

Ojciec Julii, posunięty w latach, ale zażywny i pełen energii mężczyzna, wita gości i zapędza ich do głośnego i radosnego tańca. Wkrótce scenę wypełnia kilka par zamaskowanych tancerzy, którzy - uśmiechnięci od ucha do ucha - energicznie przytupują, klaszczą, radośnie pokrzykują i wirują w układach pełnych podskoków, ukłonów i zwrotów. Melodia jest wesoła, z przewagą kobzy i fagotów, a skoczny rytm wybijają tamburyny. Nastrój zabawy udziela się nawet seniorom, a gdy siwowłosy kuzyn Kapuleta zaczyna niezgrabnie podrygiwać wśród młodzieży, gospodarz odciąga go na stronę, gdzie prowadzą pogodną rozmowę pełną żartów i nieszkodliwych złośliwości. Nic nie zapowiada nieszczęścia, a potencjał komediowy początku tej sceny jest w pełni wykorzystany. Humorystyczne jest zarówno zachowanie gospodarza, jak i niezborna krzątanina służących, a reżyserowi udało się osiągnąc efekt radosnego chaosu, aby zabawa wyglądała na spontaniczną i naturalną. Tańczący zachowują pewne ustalone układy, ale czasami pojedynczy uczestnicy obijają się o siebie czy gubią partnerów. Ważnym elementem komediowym jest ukazanie Romea jako niechętnego uczestnika zabawy, który tańcząc jedynie markuje zaangażowanie, a postawą, gestami i wyrazem twarzy manifestuje swoją niechęć do szalonych pląsów. Rozgląda się po sali, zagapia, albo głowę trzyma spuszczoną, nie skupiając uwagi na damach, a kiedy korzystając z tanecznej figury - usiłuje wymigać się od dalszego tańca, jego postawna partnerka obejmuje go wpół i siłą wciąga z powrotem w roztańczony tłumek. Romeo, melancholijny kochanek, jest więc od początku wyobcowany i na każdym kroku zdaje się przypominać, że znalazł się tu nie z własnej woli. Jego ponura mina świadczy o tym, że myślami jest gdzie indziej. Mamy więc silny kontrast między beztroską roztańczonych gości i pogodnym nastrojem tej jeszcze na razie potencjalnej komedii romantycznej a młodym Montekim, który nie dość, że jest nieszczęśliwie zakochany, to jeszcze czuje na sobie ciężar złych przeczuć. I kontrast ten jest zbudowany nie tylko poprzez wypunktowanie pojedynczej postaci na tle grupy, ale przede wszystkim dzięki temu, że grupę tworzą postacie w ruchu, w układzie mniej czy bardziej skodyfikowanego zbiorowego tańca i dopiero na takiej kanwie wyraziście odznacza się figura Romea, który w ten układ nie wchodzi albo zaburza go, myląc kroki lub nie podejmując tanecznych gestów. Jego ciało nie poddaje się rytmowi tańca.

Moment kulminacyjny sceny zostaje wprowadzony gestem o silnej wymowie metaforycznej. Kiedy Romeo po raz kolejny opuszcza tańczących i, podnosząc maskę z oczu na czoło, odchodzi na stronę, Merkucjo bierze go za ramiona $i$ bezpardonowo wrzuca z powrotem na środek sceny. W tej samej chwili rozlegają się ostatnie takty skocznego tańca, tancerze ustawieni w szeregu przesuwają się w głąb sceny i zastygają w geście ostatniego klaśnięcia, z lewymi dłońmi wzniesionymi ku górze, tyłem do widzów. Julia, znużona towarzystwem swojego partnera, także bez maski na oczach, zostaje nieco z tyłu, więc kiedy Merkucjo popycha Romea ku środkowi sceny, spojrzenia dwojga młodych krzyżują się. Na- 
stępuje trzysekundowa pauza i cisza - zamrożenie akcji. Romeo i Julia patrzą na siebie nieruchomo, zanim rozpocznie się kolejny, wolny taniec, a o Julię upomni się jej partner. Moment zatrzymania jest rozegrany bardzo naturalnie, bo można go zinterpretować jako kolejną figurę taneczną, choreograficzny łącznik między tańcem skocznym i spokojnym. Ale zarazem jest wyraźnym sygnałem, że oto los Romea popycha go właśnie w wir wydarzeń, od których nie ma odwrotu. Zaczynają się realizować zapowiedziane w prologu ,sprawy śmiertelnej miłości” (Iwa).

W Romea wstępuje jakby nowy duch; w jednej chwili opuszczają go ponure myśli i wygłasza monolog pochwalny na cześć urody Julii. Ponownie ze świetnym efektem zastosowano kontrast i znowu kluczowym narzędziem jego uruchomienia jest taniec. Jak poprzednio podskoki tańczących były tłem dla melancholii Romea, tak teraz jego płomienne poetyckie zachwyty wygłaszane $\mathrm{z}$ wzniesioną do góry promienną twarzą kontrastują ze spokojnym tańcem par z tyłu sceny. Przód sceny zdominował Romeo, miotając się z prawa do lewa w komicznym wręcz pobudzeniu. Nic dziwnego, że jego zachowanie zwraca uwagę Tybalta, który, chcąc natychmiast odpowiedzieć na zniewagę, rwie się do bójki. Entuzjazm Romea gaśnie, z niepokojem obserwuje on z brzegu sceny przebieg kłótni Tybalta z wujem. Kiedy rozgniewany Kapulet szarpnie się z siostrzeńcem, a następnie policzkuje go za nieposłuszeństwo, ich konflikt staje się na tyle głośny i gwałtowny, że muzyka milknie, a zaniepokojeni goście porzucają taniec i zwracają głowy w kierunku rozgorączkowanych mężczyzn. Pierwszy raz od początku tej sceny nie słychać muzyki, a cisza ta jest wymowną zapowiedzią rozwoju wypadków. Zabawa jest zagrożona, gospodarz więc mityguje się i zachęca gości do podjęcia przerwanego tańca. Dobry nastrój nie zostaje całkowicie zburzony, miotający się gniewie Kapulet jest nawet nieco zabawny, a goście są raczej zaciekawieni niż zaniepokojeni. Muzyka rozlega się ponownie i młodzież wraca do spokojnego tańca w parach. Melodia jest nastrojowa i nieco nostalgiczna, a układy oparte na długich sekwencjach figur, w których tancerze stoją naprzeciw siebie, trzymają się za ręce lub tylko lekko dotykają wewnętrzną stroną dłoni w powolnych obrotach. Jest to ten, wspomniany wyżej, rodzaj chodzonego, który pozwala partnerom na rozmowy i flirty. Taki przebieg tańca sprzyja zamiarom Romea, który powoli podchodzi do Julii od tyłu i bierze ją za rękę, na co ona zaskoczona obraca się ku niemu i, rozpoznając go, pozwala poprowadzić się ku środkowi sceny. Rozpoczyna się słynny sonetowy flirt. Młodzi są zupełnie pochłonięci sobą, nie tańczą - chociaż z pozoru do tego właśnie się szykowali - cały czas patrzą sobie w oczy, przepełnia ich gwałtowna radość fizycznego kontaktu i duchowego porozumienia. Są całkowicie wyjęci z tła, bo nikt nie zwraca na nich uwagi (dopóki, po drugim pocałunku, nie interweniuje czujna Piastunka). W tle delikatna melodia z przewagą spokojnego fletu i pary tańczące płynnie, posuwiście, nieco sennie, jakby w zwolnionym tempie, co powoduje, że epizod ten rozbija się wyraźnie na dwie odrębne rzeczywistości: odrealnioną nagle salę balową, pełną rodziny i gości, oraz kompletnie osobny świat zachwyconych sobą młodych.

Inscenizacja Eriki Whyman, z Ballym Gillem i Karen Fishwick w rolach głównych, jest utrzymana w zupełnie innym nastroju. Scenografia i kostiumy są uwspółcześnione, a zachowanie postaci zbrutalizowane. To świat, w którym nie 
ma miejsca na sentymenty. W tym przedstawieniu, wyraźnie mającym na celu przyciągnięcie uwagi młodszej widowni, widać inspirację klasycznym już dzisiaj filmem Baza Luhrmanna, który w 1996 roku zaadaptował dramat Szekspira w filmie Romeo + Juliet. W domu Kapuletów nie odbywa się bal, ale raczej impreza, na którą rodzice Julii zaprosili młodzież, z Parysem na czele. Pusta przestrzeń jest utrzymana w ciemnych kolorach, dominuje czerń i granat, na których tle wyróżnia się bardzo słabo oświetlona zimnym niebieskim reflektorem wydzielona przestrzeń do tańca. Jest to rodzaj szkieletowej konstrukcji, jakby altany bez dwóch ścian, w której stłoczeni goście poruszają się w zwolnionym tempie w rytm nowoczesnej elektronicznej muzyki o niepokojącym transowym pulsie. Goście nie tańczą w parach, lecz wiją się i wyginają każdy z osobna, konwulsyjnie, niczym w sennym koszmarze. Na twarzach mają maski, noszą typowe „dyskotekowe” stroje - sportowe buty, białe spodnie, obcisłe srebrne szorty, brokatowe bluzki, błyszczące kurtki i marynarki. Na tle tego kiczu wyróżniają się stonowane kostiumy głównych postaci: Julia ma narzuconą na spodnie ciemną tunikę z szerokim paskiem, a Romeo założone jedną na drugą ciemne, bawełniane bluzy.

Interesujący nas fragment sceny piątej rozpoczyna się tuż przed sonetem pocałunków. Taniec, który jest w tej inscenizacji ponurą wariacją na temat klubowej imprezy, sprawia silne wrażenie czegoś przytłaczającego i przygnębiającego, z czego nie sposób się wyrwać. Tańczący poruszają się na wyznaczonej przestrzeni niczym w transie, a wśród nich Romeo i Julia, którzy w pewnym momencie, podkreślonym za pomocą zimnego światła punktowego reflektora, znajdują się naprzeciw siebie. Najpierw spowalniają swoje taneczne ruchy prawie do zera, a moment później następuje choreograficzne rozwiązanie, które jest kluczowe dla efektu „wyjęcia z tła”. Jakby na umówiony sygnał młodzi odwracają się od siebie i robią niby taneczny zwrot wokół własnej osi, równocześnie występując z kręgu transowego tańca ku środkowi sceny. Znalazłszy się tam, pośpiesznie ściągają maski i uśmiechają się do siebie radośnie. Zastosowany zabieg wyjścia z kręgu tańczących powoduje, że ich sonetowy dialog rozgrywa się nie tyle na tle, ile poza przestrzenią ponurego tańca pozostałych uczestników sceny, a ich „osobność” jest dodatkowo podkreślona przez kontrast między przyćmionym niebieskofioletowym oświetleniem tańczących a małym kręgiem cieplejszego światła, w którym stoją. Również w tej interpretacji młodzi nie tańczą podczas swojej pierwszej rozmowy, chociaż gesty aktorów są zaprojektowane w taki sposób, aby uwidocznić aluzję do popularnej figury tanecznej, w którą wpisane było dotknięcie, lub prawie dotknięcie, wewnętrznej strony dłoni partnera. Julia - żeby zbagatelizować efekt zetknięcia się ich dłoni, rozpracować własne zawstydzenie i zyskać na czasie - parodiująco nawiązuje do tej figury, zmuszając partnera do niby tanecznego obrotu, podczas gdy Romeo nieustępliwie dąży do pocałunku, zetknięcia ust na wzór stykających się dłoni.

Rola fizyczności, cielesnej atrakcyjności jest mocno podkreślona także w interpretacji szkolnego teatru z Gungahlin, co dla aktorów amatorów występujących przed publicznością złożoną głównie z rówieśników jest szczególnie trudnym wyzwaniem. Scena rozpoczyna się od razu dynamicznie: Romeo, Merkucjo i Benwolio wpadają z rozpędem w sam środek głośnej i rozpędzonej już impre- 
zy. Jest alkohol, jedzenie, ojciec Julii ku niezadowoleniu żony zaczepia tańczące dziewczyny. Goście podrygują w szalonych pląsach w rytm przeboju A Little Party Never Killed Nobody, który - swoją drogą - zrobił szaloną karierę w innej scenie balu, w filmie Wielki Gatsby Luhrmanna z tego samego roku. Nie wiem, czy twórcy z Gungahlin tym właśnie się zainspirowali, w każdym razie wybór muzyki nie mógł być lepszy, biorąc pod uwagę pyszną ironię tytułowego refrenu. W tanecznych wygibasach przoduje żywiołowy Merkucjo, ale i Romeo nie jest gorszy. Zabawa ewidentnie zdążyła się rozkręcić, kiedy Romeo i Julia niespodziewanie wpadają na siebie, zderzając się plecami. Nic bardziej naturalnego w dyskotekowym tłumie, a zarazem świetne przejście od realizmu do teatralnej iluzji: zderzenie powoduje, że wszystkie postacie na scenie, łącznie z Julią, nieruchomieją. Tu także zastosowano ,zamrożenie” akcji, ale w sposób bardziej złożony. Najpierw tworzy ono tło dla retoryki pochwalnego monologu Romea, skierowanego wyraźnie do widzów, chociaż chłopak stoi tuż koło Julii, niemal jej dotykając. Jego słowa: „dłoń ozłocę dotknięciem jej dłoni” wyrywają Julię ze stanu znieruchomienia, a pytanie: „Kochałem dotąd?”, jest już skierowane do niej i zapowiada słowno-cielesny flirt, który ma nastąpić. Ale najpierw to oni nieruchomieją, tym razem oboje, patrząc sobie w oczy, on lekko dotyka dłonią jej nagiego ramienia, podczas gdy na pierwszy plan wysuwa się głośna muzyka i taniec wznowionej imprezy, na tle której dochodzi do kłótni Tybalta z wujem. Po czym znowu następuje teatralna stop-klatka, na której tle odegrany zostaje sonetowy flirt. Chociaż w tej inscenizacji młodzi nie tańczą ze sobą ani razu, to taneczna zabawa tworzy ramę, która jest dla Romea pretekstem do tego, aby cały czas być blisko Julii, niezależnie od tego, czy aktualnie znajduje się na planie realnym, czy na planie iluzji.

\section{Podsumowanie}

Najistotniejsza różnica między tymi inscenizacjami dotycząca wykorzystania tańca polega na odmiennie wyskalowanym uwypukleniu roli przypadku i agencji czynników zewnętrznych. W interpretacji Dromgoole’a Romeo zostaje najpierw wciągnięty w wir tańczących przez partnerkę, a następnie bezpardonowo wrzucony na środek sceny przez Merkucja. A więc bezpośrednimi sprawcami spotkania są inni: goście Kapuleta, społeczność Werony, mający dobre chęci przyjaciele. W inscenizacji Gungahlin College kluczową rolę odgrywa zbieg okoliczności. U Whyman z kolei, młodzi, wykraczając poza krąg tańca, niejako od początku biorą sprawy w swoje ręce.

Ponadto w inscenizacji RSC pomiędzy pierwszym flirtem a zakończeniem balu następuje długa sekwencja bez dialogu, która za pomocą ruchu scenicznego obrazuje istotę konfliktu leżącego u podstaw tragedii. Romeo jest zaszokowany, kiedy Piastunka uświadamia mu, kim jest dziewczyna, z którą właśnie rozmawiał. Jednak słowa „My life is my foe’s debt” (1.5.117) / „Oddałem własne życie w ręce wroga!" (Bar), które z rozpaczą w głosie wypowiada przodem do publiczności, są sygnałem do dalszej zabawy. Złowróżbna muzyka staje się głośniejsza, puls rytmu szybszy, a tancerze wylewają się z ograniczającej ich do tej pory przestrzeni i w dzikich pląsach otaczają Romea niczym w pułapce. Ten odwraca 
się ku tyłowi sceny, gdzie na dachu altany stoi Julia. Symboliczne rozłożenie sygnałów przestrzennych - Julia na planie górnym, Romeo w dole z uniesioną głową - zapowiada ,scenę balkonową”, a zarazem niemożliwość szczęśliwego połączenia kochanków. Patrzą na siebie i widać, że Romeo pragnie się z nią ponownie spotkać, a ona także po chwili zbiega do niego w dół. Tańczący spychają jednak Romea na bok i, nie dopuszczając Julii ku środkowi sceny, rozdzielają ich. Panuje mrok i hałas, młodzi rozglądają się i wzajemnie szukają. Muzyka, która staje się jeszcze bardziej energiczna i głośna, niepokojąco powtarzalna, wibrująca buczeniem elektronicznych instrumentów, zagarnia wszystkich i młodzi są zmuszeni podrygiwać wraz z innymi. Zwróceni są ku sobie, ale rozdzieleni pozostałymi, ona jeszcze promiennie uśmiechnięta, filuternie przechylając się w jego stronę, on, już przytłoczony wiedzą o jej tożsamości, z twarzą nieruchomą. Gdy wreszcie zbliżają się na tyle, aby móc przestać tańczyć, i idą ku sobie, następuje nagłe zamieszanie, słychać groźne krzyki, muzyka urywa się, na scenę wkracza ojciec, odciągając Julię na bok. Pozostali rozpraszają się, a Benwolio i Merkucjo pośpiesznie opuszczają salę, wyciągając opierającego się Romea. Grupowy ruch sceniczny w formie tańca jest w tym przedstawieniu czymś więcej niż tylko zabiegiem umożliwiającym zbudowanie tła i odosobnienie głównych postaci, czymś więcej nawet niż symbolem pokoju i harmonii zagrożonych konfliktem. Jego choreografia staje się bezpośrednim narzędziem scenograficznym służącym fizycznemu rozdzieleniu młodych, a zarazem przez swoją złowróżbność symbolizującym zły los, nieszczęście, któremu nie sposób zapobiec. Nieco podobną rolę odgrywa taniec w słynnym filmie Franca Zefirellego z roku 1968. Młodzi początkowo mają okazję tańczyć razem, ale wkrótce zostają rozdzieleni choreografią, w której panie wirują po wewnętrznym kole w jedną stronę, a panowie po zewnętrznym kole w odwrotnym kierunku. Taniec łączy więc młodych, a zarazem ich rozdziela, scena jest zaś sfilmowana w taki sposób, żeby podkreślić wysiłek, jaki oboje wkładają w to, żeby nie stracić się z oczu. Tonacja jest tutaj jednak inna: różnobarwne kolory strojów i złote światło kandelabrów podkreślają radosny nastrój, Julia promienieje szczęściem, a wesoła i energiczna moreska, której rytm wybijają założone na przeguby tańczących bransoletki z dzwonkami, wywołuje uśmiech na każdej twarzy, z wyjątkiem Tybalta. Wspominam o tym filmie dlatego, że na wiele dekad zawładnął on wyobraźnią odbiorców Romea i Julii, tak jak dekadencki film Luhrmanna dominował ją przez ostatnie dwie dekady.

W teatrze Gungahlin College taniec służy zabiegowi z gatunku metateatralnych. Kilkukrotne żonglowanie płaszczyznami ruchu i bezruchu, realizmu i iluzji, podkreśla sztuczność dyskotekowej stylizacji, a zarazem naturalność spotkania i zauroczenia dwojga młodych ludzi. Tak jak figury taneczne w inscenizacji historycznej mogą być okazją do kontaktu fizycznego w ramach dekorum, tak tutaj „niby taniec" pozwala się łączyć dłoniom, dotykać ramienia, obejmować w talii. Nienapastliwe, ale jednak stanowcze, zabiegi Romea prowadzące do pocałunku stają się swoistą choreografią flirtu, nałożoną na przystopowaną chwilowo choreografię tanecznej imprezy i współdziałającą z retoryką sonetowego dialogu.

Podczas balu u Kapuletów dochodzi do najważniejszego wydarzenia zawiązującego akcję dramatu i mającego ogromny potencjał metaforyczny - do pierwsze- 
go spotkania młodych kochanków, a także ich pierwszej rozmowy, sonetowego flirtu. Wczytując się w tę emocjonalnie intensywną scenę, widzimy jak słowo i gest, słowo i ruch, splatają się, ukazując taniec ukryty w słowach, a zarazem roztańczone słowa poezji. Niezależnie od tego, czy interpretatorzy szukają implikacji rozwiązań scenicznych w dialogu, czy też tekstowy scenariusz traktują bardziej swobodnie, widać wyraźnie, że dramat Szekspira jest wielopoziomową i precyzyjną konstrukcją zbudowaną z wielką inteligencją teatralną, a jego siłą jest otwarcie na wiele rozwiązań scenicznych różniących się między sobą subtelnymi, ale istotnymi, szczegółami.

\section{Inscenizacje}

Gungahlin College production of Romeo and Juliet, 2013, https://www.youtube.com/ watch? $\mathrm{v}=$ GlEsPBzuHkA (dostęp: 10.04.2021).

Royal Shakespeare Company, Romeo and Juliet, reż. Erica Whyman, 2018, fragment, https://www.youtube.com/watch?v=YY85VwSHFmA (dostęp: 20.04.2020).

Shakespeare's Globe, Romeo and Juliet, reż. Dominic Dromgoole, 2009, https:// www.youtube.com/watch?v=eSAIPJ0FG_0 (dostęp: 24.04.2020).

William Shakespeare's Romeo and Juliet, reż. Joan Kemp-Welch, Thames Television 1988, płyta DVD.

\section{Bibliografia (References)}

Brissenden A., Shakespeare and the Dance, New Jersey 1981.

Gibbons B., Introduction [w:] W. Shakespeare, Romeo and Juliet, London 1980.

Hazrat F., "The Wisdom of Your Feet". Dance and Rhetoric on the Shakespearean Stage [w:] The Oxford Handbook on Shakespeare and Dance, Oxford 2019, s. 217-236.

Hoskins J., The Dances of Shakespeare, New York 2005.

Long J.H., Shakespeare's Use of Music. The Histories and Tragedies, Gainesville 1971.

McGuire Ph., On the Dancing in “Romeo and Juliet”, ,Renaissance and Reformation" 1981, New Series 5, nr 2, s. 87-97.

Shakespeare W., Romeo and Juliet, red. B. Gibbons, London 1980.

Shakespeare W., Romeo i Julia, przeł. S. Barańczak, Poznań 1990.

Szekspir W., Romeo i Julia, przeł. J. Iwaszkiewicz [w:] idem, Dwanaście dramatów, t. 1, Warszawa 1999.

Sorell W., Shakespeare and the Dance, „Shakespeare Quarterly” 1957, vol. 8, nr 3, s. 367-384.

Styan J.L., Shakespeare’s Stagecraft, Cambridge 1967. 